\title{
"Amazing Together": Mason Bates, Classical Music, and Neoliberal Values
}

\author{
MARIANNA RITCHEY
}

At a 2014 summit in Las Vegas, the various corporate partners of the multinational technology corporation Cisco Systems met to network and trade ideas. The event was carefully branded, with marketing materials, speeches, and videos all advancing the summit's slogan: "Amazing Together." This slogan was also emphasized during a special performance of the Las Vegas Youth Orchestra, which played briefly for the assembled tech entrepreneurs. The piece the LVYO played was The Rise of Exotic Computing, a sinfonietta for orchestra and laptop by the 37-year-old Mason Bates. Bates, a Juilliard- and Berkeleytrained composer, is a rising star in the world of contemporary classical music; in the 2014/15 season he was the second most performed living composer in America (after John Adams). ${ }^{1}$ At the Cisco summit, he briefly introduced his piece, and then took his usual spot behind a laptop.

The LVYO played Exotic Computing while surrounded by large screens upon which images and text were projected for the duration of the performance. The screens showed footage of leaping dolphins, naval ships, farmland, assembly lines, spider webs, and outer space, with superimposed animated grids linking it all together and often imposing a sort of teleology on the visuals. In one sequence, the interlocking circles representing a dolphin's use of sonar were transformed into a naval ship's radar bleeps, an image that linked nature and technology. Overlaid on top of these images were segments of text, associating the sounds and visuals with Cisco's corporate slogan: "We are all connected... one universe... one planet... one ecosystem... thriving as one network... working with one purpose... we are amazing together." ${ }^{2}$

Cisco had donated money to the LVYO, so the group's performance at the corporate summit served as a demonstration of the company's socially minded endeavors to support not only young people, but also the kind of "high culture" that classical music still represents in the popular consciousness. ${ }^{3}$ But the music the LVYO played revealed much more than simply a display of philanthropy; Mason Bates, who was recently named the Kennedy Center's first-ever composer-in-residence, is especially applauded for his incorporation of new technologies into orchestral music. ${ }^{4}$ Most of his work makes use of drum machines and techno beats, and-as I will discuss below-many of his compositions programmatically uphold the lofty ideals of technological innovation and entrepreneurialism. The Rise of Exotic Computing is built out of tiny motives passed quickly from instrument to instrument. It is meant to aurally depict synthetic

This article was updated August 29, 2017.

I would like to thank Andrea Moore, Joanna Love, David Blake, and Klara Moricz for reading versions of this article. I would especially like to thank the anonymous readers for Music and Politics, whose substantive, focused feedback made revising the article a real pleasure.

${ }^{1}$ See the Boston Symphony Orchestra's database of seasonal statistics on American orchestras:

http://bsomusic.org/stories/the-orchestra-season-by-the-numbers-database.aspx.

${ }^{2}$ This performance is available on YouTube: https://www.youtube.com/watch?v=stPjtLh3h-A.

${ }^{3}$ The partner summit is held in a different city each year; Cisco makes a one-time donation-which they call a "local giveback" - to a local organization in each city, often a youth and/or music organization (for example, the 2013 local giveback was to the Boston Children's Chorus).

${ }^{4}$ See the Kennedy Center's press release, in which Bates is called "innovative" and "an innovator," and is credited with having "moved the orchestra into the digital age:" http://www.kennedy-center.org/about/mason-bates.cfm. 
computing, a process that links countless computers together by instantaneously replicating lines of code without human intervention. Thus the piece essentially presents Cisco's product (networking technology) as art. ${ }^{5}$ The video that accompanied the performance accomplished a similar presentation, by linking manmade technologies with naturally-evolving processes like dolphin sonar. The whole performance naturalized technological innovation and universal connectivity, linked those processes to the timeless grandeur of art, and presented them as the reason we are able to be "amazing together." In this way, it fit in nicely with the corporate branding strategy of Cisco and its partners.

In what follows, I will reveal some of the ways that Bates has found success by aligning familiar rhetoric concerning classical music's universality with nearly identical rhetoric promoting technological innovation. These rhetorical tactics activate revolutionary language while actually serving capital, which is a major feature of neoliberal rationality. Ultimately, I argue that Bates's success has been achieved at least in part by his ability to align his music_and, by extension, "classical music" itself-with the values of America's neoliberal elite. Such a merger of classical music with the neoliberal value of innovation has become commonplace in the discursive practices of many young composers and musicians in the U.S. On the one hand, this represents a pragmatic attempt to carve out a new market niche for classical music in the contemporary world; but on the other hand, I will argue that it also helps to further entrench neoliberal ideology into the common-sense worldviews of artists, audiences, and society at large.

That the contemporary financial elite would patronize a symphony orchestra and a young composer should come as no surprise. Art music composers and performers have a long history of appealing to those with money and power. Much of the great music of the past was written with at least one eye toward pleasing the financially solvent of a given era, and thus, changing musical aesthetics have often accompanied changes in the ideals of those with the most power and money in a society. The Ciscofunded performance of Exotic Computing is certainly nothing new; however, the structure in which wealthy people and corporations can become patrons of the arts-as well as what they choose to patronize- has changed, and along with that change has come a shift in cultural beliefs, tastes, and, inevitably, the practice of music. These social transformations are tied to changes capitalism itself has undergone since the early 1970s, when the doctrine of neoliberalism began to be widely propagated in the U.S. and abroad. In seeking to understand Mason Bates's phenomenal success, as well as the condition of art music in the U.S. today, it is crucial to understand some of the ways contemporary American culture has become imbued with a neoliberal ideology.

\section{Neoliberal Ideology}

"Neoliberalism" is so called because it seeks to revive the type of economic liberalism Adam Smith advocated for in The Wealth of Nations (1776). ${ }^{6}$ Milton Friedman and the other University of Chicago economists who established the central principles of neoliberalism during the 1950s and 60s asserted that all social problems_-poverty, inequality, and crime-have their roots in an over-regulated market. They believed that the best way to forge an egalitarian society would be to allow markets unrestrained freedom, because-as Smith argued—a truly free market, into which individuals entered voluntarily, would be

\footnotetext{
${ }^{5}$ The Yahoo Finance listing for Cisco details its bewildering array of holdings in every sector of business related to the internet: https://finance.yahoo.com/q/pr?s=CSCO+Profile.

${ }^{6}$ Neoliberal economics are, however, not identical to the ideas of Adam Smith; rather, neoliberals evoke Smith as a rhetorical strategy, in an attempt to give their disruptive theories a respectable historical precedent.
} 
fundamentally rational and thus incapable of causing injustice. These ideas fermented throughout the 1970s, and provided the foundation of Thatcher's (and then Reagan's) reorganization of economic life in the early 1980s, and have since spread across the world via the "structural adjustments" imposed on bankrupt cities and developing nations by the World Bank and IMF in exchange for debt relief. ${ }^{7}$

In fetishizing freedom, the economists of the Chicago School were responding to what were, for them, the very present threats of fascism and communism, social structures that they perceived as having dire consequences for individual liberty. ${ }^{8}$ As such, neoliberal rhetoric plays on powerful feelings about freedom and choice, and on the fear that these might be compromised by regulatory institutions. It is under this sort of rubric that labor unions are demonized (for limiting individual workers' ability to negotiate their own labor contracts or to move freely between industries), public utilities are privatized (because market competition provides consumers with more choices), and developing countries are opened up to foreign investment (because everyone ought to have the freedom and choice that market competition provides). As many have observed, the ideological power of the belief that market freedom will guarantee individual freedom has only grown greater with time, even as its realization proves increasingly elusive. ${ }^{9}$

Neoliberalism prizes two ideals that are helpful in understanding the contemporary American classical music landscape, and Mason Bates in particular. These are the concepts I will focus on throughout my examinations of two of Bates's creative projects: The Rise of Exotic Computing, and his work with the YouTube Symphony Orchestra.

First, neoliberalism encourages relentless innovation, particularly technological innovation. ${ }^{10}$

\footnotetext{
${ }^{7}$ Friedman and his colleagues were responding to the "Keynesian" economic theories that had increasingly shaped capitalist democracy after World War II, and argued that in spite of the low unemployment and stable rate of inflation Keynesianism promoted, it nonetheless placed untenable restrictions on individual liberty by allowing the state to regulate markets. Daniel Stedman Jones has pieced together the evolution of neoliberal thought from postwar anti-Keynesianism to the contemporary era in Masters of the Universe: Hayek, Friedman, and the Birth of Neoliberal Politics (Princeton: Princeton University Press, 2012).

${ }^{8}$ See for example Friedman's Capitalism and Freedom, in which he sets forth a powerfully-felt argument that free markets are the surest way to guarantee individual liberty and choice, as they allow citizens to support themselves economically even when governments seek to repress them. He contrasts this social organization with communism, in which every citizen works directly for the government and thus has no recourse against state oppression (Chicago: University of Chicago Press, 1962). Earlier, Friedrich von Hayek made a similar argument, insisting that governmental regulation of markets led ultimately to both socialism and fascism (which for him were more or less interchangeable), in The Road to Serfdom (Chicago: University of Chicago Press, 1944). See Luc Boltanski's and Eve Chiapello's The New Spirit of Capitalism (trans. Gregory Elliott) for a foundational study of the infiltration of the rhetoric of "freedom" into managerial and governmental capitalist discourses and labor intensification beginning in the 1970s (London: Verso, 2005).

${ }^{9}$ For further reading on the transmutation of free market policies into moral beliefs, see Jamie Peck, Constructions of Neoliberal Reason (Oxford: Oxford University Press, 2010); David Harvey, A Brief History of Neoliberalism (Oxford: Oxford University Press, 2005); and Wendy Brown, "Neoliberalism and the End of Liberal Democracy," in Edgework: Critical Essays on Knowledge and Politics (Princeton: Princeton University Press, 2005). For a book-length study of just one example of how this transmutation of capitalist values into everyday beliefs occurs, see Silvia Federici's extensive history of the transition from medieval feudalism to contemporary market capitalism, in which she argues that misogynist patriarchy is a necessary and ongoing feature of capitalist accumulation: Caliban and the Witch: Women, the Body, and Primitive Accumulation (New York: Autonomedia, 2004).

10 "Innovation" is perhaps the most prevalent keyword used by economists, politicians, funding organizations, and journalists who subscribe to neoliberal ideals. Milton Friedman argued that "experimentation" as a broadly-adhered to social value is what will bring "tomorrow's laggard above today's mean" (Capitalism and Freedom, 4). Elsewhere, he upholds the great potential of innovation to contribute to individual freedom by demonstrating that most technological innovations in history have benefited "the ordinary person," rather than the wealthy. See Milton Friedman and Rose Friedman, Free to Choose: $A$ Personal Statement (Orlando: Harcourt, 1979). Two recent examples of books by academic economists who optimistically explore innovation's role in successful economic policy are: Robert Atkinson and Stephen Ezell, Innovation Economics: The Race for Global Advantage (New Haven: Yale University Press, 2012); and William H. Janeway, Doing Capitalism in the Innovation Economy (Cambridge: Cambridge University Press, 2012). See also the Harvard Business Review, which sponsors
} 
Rhetorically, innovation is valorized as a manifestation of individual creativity and originality, while in practice constant technological innovation keeps the cost of labor low, because the necessity for workers to repeatedly learn new skill sets and change industries limits their ability to attain stable labor contracts or to unionize. ${ }^{11}$ This is perhaps the most obvious way that neoliberal values articulate with Bates's music. In interviews, he unproblematically valorizes technological innovation, but he also glorifies it programmatically in much of his music. His Garages of the Valley, for example, is a symphonic work honoring "the garages that dot the landscape of Silicon Valley [that] housed the visionaries behind Apple, Hewlett-Packard, Intel, and Google." ${ }^{12}$ In July, Bates premiered an even more focused apotheosis of a tech entrepreneur: an opera, titled The (R)evolution of Steve Jobs (commissioned by the Santa Fe Opera), which depicts Jobs' trajectory from his roots as an idealistic hippie to his late-in-life attainment of a "deeper understanding of true human connection." 13

The second way neoliberal values interpolate with Bates's career is via a rhetoric of universality meant to ground disruptive innovations within a framework of timeless truth. Despite their fetishization of the new and innovative, neoliberal thinkers are also concerned with aligning their economic ideas with vague historical or natural precedents, in an attempt to present free market ideals as naturally-occurring, universal truths. In its revivification of eighteenth- and nineteenth-century economic ideas, neoliberalism hearkens back to a mythical economic Golden Age, and seeks to return society to a healthy path by evoking the more righteous ideals of past eras. ${ }^{14}$ Similarly, neoliberals often identify their economic ideas as merely manifestations of "human nature" or "human instinct," thus attempting to naturalize and universalize what are, in reality, very recent developments in Western economic history. ${ }^{15}$

Just as neoliberals anchor their modern theories in the idealized past, Bates consistently aligns himself with the great programmatic nineteenth-century composers, presenting himself in interviews and blog essays as the direct descendant of Berlioz and Liszt. ${ }^{16}$ For Bates, this lineage is a crucial part of his selfpresentation. He routinely declares that his use of electronics in symphonic composition is not avant-

the "Innovating Innovation Challenge" each year, and which recently published an article, titled "Who's the Best at Innovating Innovation?" in which the author, Polly LaBarre, demands that businesses work harder to "build innovation into the values, processes, and practices that rule everyday activity and behavior" (February 25, 2013, https://hbr.org/2013/02/whos-the-best-at-innovating-in/).

${ }^{11}$ The conception of capitalism as an evolving process became the core of the German economist Joseph Schumpeter's work. Schumpeter, a major influence on (and mentor to) Milton Friedman, provided the foundation for contemporary ideas about innovation and the economy by enlarging on Marx's notion of "creative destruction," a term meant to describe the inevitable crises constant innovation generates within the capitalist system. See Joseph Schumpeter, Capitalism, Socialism, and Democracy (New York: Harper \& Brothers, 1942).

${ }^{12}$ Description on Mason Bates's blog: www.masonbates.com/work/work-garages.html.

${ }^{13}$ I reviewed this opera for the American Musicological Society's blog, Musicology Now. See: http://musicologynow.amsnet.org/2017/08/the-revolution-of-steve-jobs.html?m=1.

${ }^{14}$ Friedman's Capitalism and Freedom explicitly conflates the ideal of the free market with democratic freedom. The book argues that "competitive capitalism" is "a system of economic freedom and a necessary condition for political freedom" (4), and that democracy is the only system of government that can "guarantee" this political freedom (8). For an analysis of one contemporary example of market freedom being conflated with democratic freedom, see David Harvey's discussion of the way the word "freedom" was used in political speeches to justify the deregulation and privatization of the Iraqi economy in the wake of the U.S. invasion (Harvey, A Brief History of Neoliberalism, 6).

${ }^{15}$ See for example in the respected economist Deepak Lal's book advocating a return to classical liberalism, in which he asserts that the basic model for all "human nature" is homo economicus, meaning that "human beings are self-interested and rational: maximizing utility as consumers and profits as producers." Reviving the Invisible Hand: The Case for Classical Liberalism in the Twenty-First Century (Princeton: Princeton University Press, 2006), 151.

${ }^{16}$ See Bates's blog: In an entry about his piece Alternative Energy, he compares it to "the tone poems of Berlioz and Liszt," and in an extended essay titled "The Mechanics of Musical Narrative," he locates himself firmly within the music-historical lineage of the "programmatic approach" to composition that he says was pioneered by Berlioz and further explored by Beethoven in the $9^{\text {th }}$ Symphony (http://www.masonbates.com/blog/the-mechanics-of-musical-narrative/). 
garde, but simply a logical application of traditional ideas about classical music, which he says has "always" been engaged in technological innovation. In some ways Bates's innovation fetish might seem to mirror that of postwar modernism, but, crucially, he does not couch his love of technology in terms of science or research, or in terms of a desire to transcend the past (as was the case with the artists who worked at IRCAM in the 1970s and 80s, for example). Rather, he is interested in combining what he calls the worlds of classical and popular music, as a means of attracting new audiences and presenting a classically-inflected musical spectacle that is in step with the times, in a market-oriented sense. For Bates, technological innovation is a programmatic subject and an entrepreneurial tactic for appealing to audiences, rather than a model for compositional practice as it was for the postwar modernists. Furthermore, where modernists like Pierre Boulez tended to be interested in computer-generated music for what they perceived as the greater degree of autonomy such music enabled, Bates could not be less invested in notions of musical autonomy, a critical doctrine he has (not inaccurately) described as "macho."17

By presenting his music in this way-as both ultra-contemporary and market-oriented as well as a manifestation of universal values-Bates has attained a high degree of visibility and prestigious patronage, from classical music institutions as well as newer financial giants like Cisco Systems and Google.

\section{Musical Economics and a New Elite}

Since Attali's influential examination of the relationships between music and its modes of production throughout time, analyses of music and economics have proliferated. ${ }^{18}$ Authors have approached the topic from many different perspectives; where Attali wrote generally about music production in culture, others have worked materially to "follow the money," linking composers and compositions to specific funding sources. ${ }^{19}$ My project is especially in dialogue with the emerging body of scholarship on neoliberalism, entrepreneurialism, and the practice of contemporary classical music in the U.S., particularly the work of Andrea Moore, William Robin, and John Pippen. ${ }^{20}$

However, scholarship on older music has examined similar historical instances when musical aesthetics and rhetoric changed drastically in order to maintain music's relevance within a changed social dynamic. Celia Applegate pursues this kind of historical analysis in her intervention into the discourse

\footnotetext{
${ }^{17}$ Mason Bates, “The Mechanics of Musical Narrative,” masonbates.com (2011), http://www.masonbates.com/blog/themechanics-of-musical-narrative/.

${ }^{18}$ Jacques Attali, Noise: The Political Economy of Music, [Bruits: essai sur l'économie politique de la musique], trans. Brian Massumi (Minneapolis: University of Minnesota Press, 2006 [Paris: Universitaires de France, 1977]). See Eric Drott's recent appraisal of Attali's canonical work, "Rereading Jacques Attali's Bruits," Critical Inquiry 41, no. 4 (Summer 2015), $721-756$. Also influential in beginning these kinds of scholarly explorations was Howard Becker's Art Worlds, which provided a material view of the social, economic, and geographical elements that delineate what counts as "art" in a given culture (Berkeley: University of California Press, 1982).

${ }^{19}$ A handful of chronologically-diverse examples of economically-engaged musicology: William Weber, ed., The Musician as Entrepreneur, 1700-1914: Managers, Charlatans, and Idealists (Bloomington: Indiana University Press, 2004); Richard Crawford, The American Musical Landscape: The Business of Musicianship from Billings to Gershwin (Berkeley: University of California Press, 1993); Iain Fenlon, ed., Music in Medieval and Early Modern Europe: Patronage, Sources and Texts (Cambridge: Cambridge University Press, 1981); and ongoing work by musicologists engaged in establishing a field of what might be called "patronage studies," for example the papers given at the panel "Toward a Theory of Musical Patronage Post1900 " at the Milwaukee meeting of the AMS, and the conference "Who Pays? Who Plays? Patronage and Entrepreneurship in American Music" at the University of Redlands in October 2015.

${ }^{20}$ Andrea Moore, "Neoliberalism and the Musical Entrepreneur," Fournal of the Society for American Music 10, no. 1 (2016), 3353; John Pippen, "Toward a Postmodern Avant-Garde: Labour, Virtuosity, and Aesthetics in an American New Music Ensemble," (PhD diss., University of Western Ontario, 2014); Will Robin, "A Scene Without a Name: Indie Classical and American New Music in the Twenty-First Century” (PhD diss., University of North Carolina, Chapel Hill, 2016).
} 
surrounding musical autonomy and "absolute" music. Applegate argues that in their essays on the transcendent superiority of instrumental music, critics like E.T.A. Hoffmann and A.B. Marx were trying to make music interesting to the educated philosophers who had replaced the hereditary nobility as the economic and political elite in the post-revolutionary era. ${ }^{21}$ These newly powerful thinkers, influenced by Kant, had a low opinion of music's status as an art form of legitimate interest. New ideas about instrumental music's superior aesthetic autonomy thus aligned well with the "philosophical project of neohumanism" that had become a dominant value of the new Germanic elite. Applegate insists, however, that although music theorists successfully inserted music into the reigning philosophical framework of the time, "securing intellectual prestige would not have mattered so much to musicians themselves had not access to funding and support, whether state or private, depended on such distinction." ${ }^{22}$ Rather than advancing a nationalistic or even a spiritual agenda, then, Hoffmann and Marx were simply being pragmatic in pursuing new avenues of economic patronage for what was fast becoming a "breadless art." ${ }^{23} \mathrm{I}$ would argue that a similarly pragmatic transformation of musical sounds, presentations, and critical values is currently underway in art music composition in the U.S., and that this transformation is conditioned by the new forms that capitalism and financial power have taken since the 1970s.

Superficially, as mentioned above, the connection between Mason Bates and autonomous music may seem murky. Bates violates every principle of musical autonomy articulated by Hoffmann and Marx. He composes almost nothing but program music, much of it very short and structurally simple; he advocates for the inclusion of visuals and texts in the performance of instrumental music, including performances of canonical works of the past; and he is ruthlessly, unapologetically crowd-pleasing. Nonetheless, I would argue that he is engaged in a project very similar to the one Applegate diagnoses in eighteenth-century music criticism. Bates routinely strives to insert ideas about his own music-and "classical music" generally-into the value system adhered to by the new financial elite. His introductory remarks at the Cisco partner summit situate the musical performance as a natural outgrowth of Cisco's most cherished prerogatives; before beginning the piece, he reassured the roomful of powerful tech executives that "the orchestra has always been connected to technology" and that "the sounds of the digital age can be a part of the symphonic scene."

Bates effectively mythologizes neoliberal beliefs about technological innovation and universal accessibility by cloaking them in the sense of virtue that adheres to classical music. In interviews, blog essays, and in his own music, Bates is remarkably consistent in conflating technology and traditional art music; however, this rhetorical conflation is perhaps nowhere more apparent than in his work with the YouTube Symphony Orchestra.

\section{The YouTube Symphony Orchestra}

Mason Bates's short piece for orchestra and laptop, Mothership, was commissioned in 2010 by longtime supporter Michael Tilson Thomas for the second performance of the YouTube Symphony Orchestra (YTSO), and Bates himself served as a consultant and creative partner in the planning,

\footnotetext{
${ }^{21}$ Celia Applegate, "How German Is It? Nationalism and the Idea of Serious Music in the Early Nineteenth Century," $19^{\text {th }}$ century Music 21, no. 3 (1998), 274-296.

${ }^{22}$ Applegate, "How German Is It?," 286.

${ }^{23}$ Klaus Hortschansky attributes this quotation to the eighteenth-century composer J.W. Hässler. See "The Musician as Music Dealer in the Second Half of the $18^{\text {th }}$ Century," Social Status of the Professional Musician from the Middle Ages to the $19^{\text {th }}$ Century, ed. Walter Salmen, trans. Herbert Kaufman and Barbara Reisner (New York: Pendragon Press, 1983).
} 
promotion, and execution of the performance. The YTSO was conceived by the consulting agency 21C Media Group, a New York City-based PR and marketing firm that specializes in classical music and the performing arts. ${ }^{24}$ In 2008, Google hired the firm to come up with what marketing materials described as "a new worldwide initiative to promote talent around the world and raise visibility for high-quality content on YouTube." In all, 101 musicians from thirty countries were chosen based on audition videos they uploaded to the site in December 2008. The winners traveled to New York City for a grand performance at Carnegie Hall, where the audience was treated to an evening of classical music, accompanied by a display of cutting-edge digital projection. The project was repeated in 2010, with another round of auditions, and a final performance at the Sydney Opera House in March 2011 that was also streamed live to millions of viewers online. The program for the Sydney concert included three new works, and one excerpt by the Argentinian composer Alberto Ginastera; the rest of the night was devoted to well-known pieces and excerpts by canonical European composers of the past: Berlioz, Mozart, Schumann, Schubert, Stravinsky, Mendelssohn, Strauss, and J.S. Bach. ${ }^{25}$

The YTSO project was, by almost all accounts, a great success. ${ }^{26}$ The first iteration of the project received the most press mentions of any performance in Carnegie Hall's history, and the second performance was watched online by over a million people. The YTSO project had wide appeal because of its use of the technological innovation of the internet to bring together people from all over the world, as well as for its display of multiculturalism - a discursive value that emerged in the U.S. educational reforms of the 1970s and that is now incorporated into the management strategies and business plans of corporations like Google. The YTSO was designed to be an inspiring celebration of the way the performance of music with universal appeal, when combined with the world-changing technology of the internet, can peacefully unite people from diverse cultural backgrounds.

It had another purpose too. Ed Sanders, YouTube's Director of Marketing, told me that the YTSO was meant to sculpt a new "all-around brand perception" for the YouTube site, given that, at the time, "a lot of people saw YouTube as this repository of crap videos, basically." ${ }^{27}$ YouTube intended the YTSO project to establish the site as a purveyor of high-class culture, combating its widespread association with what Carol Vernallis calls its "whoopee cushion" aesthetic: short, vulgar, comedic, and instantly gratifying. ${ }^{28}$ In designing and executing the YTSO project, Sanders collaborated with many high-profile professional classical musicians from orchestras around the world, as well as the American conductor Michael Tilson Thomas, the Chinese composer Tan Dun, and Mason Bates. A New York Times article about the project noted that it was part of a corporate strategy to "gussy up YouTube content and make the

\footnotetext{
${ }^{24}$ 21C Media Group has produced videos for the New York Philharmonic, and in 2010 they produced the $40^{\text {th }}$-anniversary concert for the World Economic Forum.

${ }^{25}$ The entire YTSO Sydney performance is viewable on the YTSO's YouTube channel: https://www.youtube.com/watch?v=LnKJpYGCLsg.

${ }^{26}$ Certainly YouTube and Google considered it a success from a marketing standpoint ("People are still talking about it," YouTube Marketing Director Ed Sanders told me), but even arts journalists who testified to the subpar musicianship on display nonetheless praised the project as a whole: on his blog, the widely-read classical music activist Greg Sandow wrote that although the musicianship was bad and the actual concert "disappointing," he nonetheless loved the way it gave classical music "the kind of multimedia treatment pop concerts get," and said he believes that "this event helps classical music" by making it seem "far more accessible and interesting than it did 10 years ago." Anthony Tommasini concluded his review of the Carnegie Hall performance in a New York Times article on April 16, 2009, by saying that "after all the spoken and video tributes to YouTube and Google, you can only hope that this project becomes permanent," a surprising conclusion given his lukewarm assessment of the actual musicianship the project displayed.

${ }^{27}$ Ed Sanders, interview with the author, April 11, 2016.

${ }^{28}$ Carol Vernallis, Unruly Media (Oxford: Oxford University Press, 2013), 127.
} 
site more attractive to advertisers." ${ }^{29}$ Sanders, on the other hand, characterized the project in grander terms: "we wanted to give people a peek into what makes YouTube wonderful, and how technology can revolutionize things like democracy, things like accessibility..." Sanders also said that the project represented "a challenge issued to a very old art," meaning classical music, which he several times described as needing to "innovate or die."

However, for Bates, Tilson Thomas, and many of the performers, the project's goal was not so much to increase YouTube's revenues as it was to advocate for classical music's "relevance" in today's fastpaced, technologically-mediated world. Tilson Thomas repeatedly referred to classical music as an "ongoing" tradition, and both Tilson Thomas and Bates praised classical music's unique ability to "bring us together." On the one hand, privileging technological innovation and arguing for classical music's relevance would seem to be almost mutually exclusive propositions. But, crucially, both these agendas were carefully advanced via the same powerfully-resonant rhetoric, one that promoted the universality of both classical music and technological innovation, equally.

Throughout the YTSO performance in Sydney, both classical music and YouTube were deliberately associated with supposedly universal values. Various commentators throughout the evening hailed the miraculous technological innovation of YouTube for enabling a "diverse" humanity's engagement with the "universal" appeal of classical music, and described the internet itself as "inherently democratic." The performance was also accompanied by a high-tech visual spectacle, in which digital painting (made by Obscura Digital, who also created digital artwork for the "Amazing Together" Cisco partner summit) was projected live during every piece, on every surface of the opera house including its exterior. ${ }^{30}$ Along with the digital paintings, periodic close-ups of performers and heavily edited inspirational videos about selected musicians were projected intermittently. This display of cutting-edge technology was implicitly presented as a fundamental aspect of the classical music on offer; during one of his speeches, Tilson Thomas noted that classical music has "always" been a part of such technological innovation. Many of the musicians' video interviews routinely apotheosized both classical music and technology as similarly (sometimes interchangeably) totalizing forces for democratic global unity in a world of marvelous multicultural diversity. "I have put my entire career in the hands of the internet. These are my teachers," said violinist Stepan Grytsay, who taught himself to play by watching YouTube videos of virtuosos both living and dead. Tilson Thomas, Bates, and the performers thanked classical music and technology again and again for the way they encourage individual innovation while also "bringing us together."

The introductory video at the Sydney performance showed a montage of images intended to evoke countless places and cultures, overlaid with the text: "From the sands to the seas, from the forbidden city to the city that never sleeps, from their own world to the whole world: 33 countries, 5 continents, 101 musicians, 1 stage." Throughout the evening, multiple speakers emphasized the global nature of the project as well as the universality of classical music itself, which was described several times as a universal language that speaks to what is "human" in "all of us."

In line with this universalizing strategy, classical music and the internet were not only rhetorically conflated but were also positioned as being stronger avenues for collaboration than traditional ones based on shared national, ethnic, or linguistic cultures. For example, the Turkish violinist Ozgur Baskin insisted on classical music's superior universality in his introductory video: "Nobody knows the real Turkey," he

\footnotetext{
${ }^{29}$ Daniel J. Wakin, “Getting to Carnegie via YouTube,” The New York Times (December 1, 2008).

${ }^{30}$ The YTSO performance was the first time images were projected onto the exterior of the opera house, although since then this has become routine.
} 
said, "most of them think we are riding camels...we are bad, or, you know...terrorists." Over footage of his family playing nineteenth-century European chamber music together, Baskin pleaded, "please come see the real Turkey."

As Baskin's statement indicates, the universal appeal and accessibility of classical music often rubbed awkwardly against the YTSO's equally common praise of its inherent diversity. Words and phrases like "all cultures," "global" and "the whole world" were uttered again and again, describing both the YTSO and classical music, and yet the event seemed exclusively oriented toward a contemporary Americanized audience. Every presenter, and almost every musician, spoke English in their informational video (despite the obvious possibility the videos presented of using subtitles), and of the three new compositions that were performed, two were by Americans (Bates and Colin Jacobsen, a violinist and co-founder of the Brooklyn ensemble The Knights). The other was a piece for solo didgeridoo by the aboriginal Australian composer William Barton, which Tilson Thomas introduced by saying "Australia has an ancient indigenous tradition of music-making that also goes way back in time." However, Barton's piece was far from a straightforward celebration of an indigenous aesthetic. Rather, it was comprised primarily of signifiers from American pop music: beatboxing; the performer "moonwalking" with his fingers; and his repeated yelling_in English—of “check this out!" to gales of audience laughter.

The YTSO's display of a particular type of Westernized multiculturalism is in keeping with neoliberal rhetoric, which promotes cultural diversity as an extension of individuality, but only insofar as that diversity is still amenable to free-market capitalism. In fact, the anthropologist Charles Hale goes so far as to argue that its commitment to this very specific type of marketable multiculturalism is what puts the "neo" in "neoliberal." 31 The YTSO project helped spread the perception that Google's corporate manifesto—with its emphasis on diversity and global outreach—represents the highest values of humanity, and it produced multiculturalism as a spectacle that commodified difference and diversity while also establishing which types of difference were "good" and "bad" within the context of Western capitalism. Both the project and its centerpiece-Bates's Mothership-aestheticized corporate-driven efforts to deploy official discourses of multiculturalism as a means of constructing consent for globalization.

However, the YTSO project's commitment to neoliberal values goes much deeper than its rhetorical glorification of the universally liberatory potential of technological innovation and its foregrounding of marketable multiculturalism. Additionally, the project also relied on joyfully-provided free labor. Workers under neoliberalism are induced to work for free by a variety of new cultural imperatives. The belief that individuals ought to "do what they love" without thought of payment has become widespread, for example. ${ }^{32}$ Similarly, people-especially but not exclusively young people-are increasingly forced to compete for unpaid internships in order to get a foot in an industry's door. The proliferation of "do what you love" advice and the cultural acceptance of unpaid internships as a necessary rite of passage both mask

\footnotetext{
${ }^{31}$ Charles R. Hale, 'Neoliberal Multiculturalism: The Remaking of Cultural Rights and Racial Dominance in Central America,' PoLAR 28, no. 1 (May, 2005), 10-28. For more on the way multiculturalism has been turned into a corporate value see: Avery Gordon and Christopher Newfield, eds., Mapping Multiculturalism (Minneapolis: University of Minnesota Press, 1996); and Jodi Melamed, Represent and Destroy: Rationalizing Violence in the New Racial Capitalism (Minneapolis: University of Minnesota Press, 2011).

${ }^{32}$ For a few examples of this cultural trend, see Microsoft's recent sponsored tweets that proclaim "passion and purpose beat pay," and that present graphed data showing that America's top CEOs care more about "creating something significant" than they do about salaries; the widespread use of Steve Jobs' quote, "the only way to do great work is to love what you do," which has been implemented into a countless number of motivational jpegs proliferating across the internet; and even the datadriven arguments of Richard Florida's urban development studies, which show that "creative" people who follow their passion (instead of trying to get stable employment) are now driving the American economy. The Rise of the Creative Class, and How its Transforming Work, Leisure, Community and Everyday Life (New York: Basic Books, 2002).
} 
the enormous amounts of free labor that such pursuits provide. It is also worth noting that much of what is produced on the internet—particularly on social media sites and sites like YouTube itself—consists of unpaid "user-generated content," meaning photos, videos, reviews, essays, and promotional material that internet users upload for free to sites that use this content to make millions of dollars in advertising revenue. ${ }^{33}$

The YTSO project was made possible by what were essentially unpaid internships; with the exception of a few star performers like Bates and the organ virtuoso Cameron Carpenter, the orchestra consisted solely of non-unionized, volunteer musicians. ${ }^{34}$ They rehearsed for two days, for eight and thirteen hours at a stretch, which was possible because Tilson Thomas was not beholden to union rules. Thus, in spite of its utopian rhetoric the YTSO capitalized on a trend in the American labor economy away from stable employment conditions and toward precarious, part-time, freelance careers, in which individuals must compete for a shifting array of low- or no-paying jobs in multiple fields simultaneously. Far from seeking to disguise this fact, however, the project's rhetoric actively publicized it, upholding the orchestra's success as an example of what becomes possible when individuals use the freedom of the internet to "do what they love." The fact that this joyful event was providing free labor to Google, which had designed the project explicitly in an effort to increase advertising revenues, was never mentioned.

\section{Mothership}

The premiere of Bates's Mothership was the centerpiece of the Sydney performance, and, in keeping with the rhetorical trends of the evening, its presentation evoked the wonder of music's status as a universal language, in combination with the righteousness of technological innovation. ${ }^{35}$ The piece combines traditional orchestral sounds and techniques with a constant stream of pulsing beats and electronic noises. The music is highly dramatic, and pushes relentlessly forward, driven by the motoric drum machine, which Bates played live with the YTSO in Sydney. The piece, like so much of Bates's music, weaves tiny, repeated melodic and rhythmic motives into a thrumming ostinato that grows dramatically with multiple build-ups of tension and climactic release. ${ }^{36}$ In keeping with most of his work,

\footnotetext{
${ }^{33}$ See Yiannis Mylonas, "Amateur Creation and Entrepreneurialism: A Critical Study of Artistic Production in Post-Fordist Structures," tripleC: Communication, Capitalism, and Critique 10, no. 1 (January 2012): 1-11. Philip Mirowski also details the ways Web 2.0 platforms like Wikipedia, YouTube, and Twitter "sucker" people into providing free content for corporations (Mirowski, "Postface: Defining Neoliberalism"), while Jakobsson and Stiernstedt argue that such "immaterial labor" is a new form of “dispossession of users' means of production," where what is being dispossessed is “users' creativity, imagination, communication, and autonomy (Peter Jacobsson and Fredrik Stiernstedt, "Pirates of Silicon Valley: State of Exception and Dispossession in Web 2.0," First Monday 15, no. 7 (July 2010), http://firstmonday.org/ojs/index.php/fm/article/view/2799). See also Tiziana Terranova's article on the "shamelessly exploitative labor" of what has come to be called "Web 2.0" content creation, "Free Labor: Producing Culture for the Digital Economy," Social Text 18, no. 2 (Summer 2000): 33-58.

${ }^{34}$ Although Google has not revealed how much the YTSO performance cost, from piecing together information in various interviews and reviews of both performances it seems that the corporation paid for musicians' airfare and visa costs, and also paid normal fees to Tilson Thomas, Bates, and the star soloists featured throughout the program.

35 "Mothership" is also the title of a legendary album by Parliament Funkadelic, a band that similarly foregrounded space exploration and technology in their live concerts, albeit with a very different intent: where Bates's piece is meant to represent different cultures being brought together by technology, the Funkadelic Mothership represented the idea of black people triumphantly separating from racist white culture. I do not believe Bates intended his piece as a referent or homage to Funkadelic; I can find no evidence that he is aware of this earlier Mothership.

${ }^{36}$ Mothership is scored for full orchestra, plus harp, piano, and electronica. My discussion of this piece refers to the published score (Aphra Music, 2012). All of Bates's scores are distributed through Bill Holab Music (www.billholabmusic.com). Several different performances of Mothership are also available on YouTube, including the one with the YTSO in Sydney (https://www.youtube.com/watch?v=PFh7LAFel4w). Additionally, the Ohio University Wind Symphony has recorded an arrangement of Mothership, which is commercially available on a recording (called Mothership) put out by Mark Records (50261-MCD).
} 
Mothership is also programmatic; we are meant to hear the orchestra as a futuristic spaceship that peaceably visits alien lands. Bates foregrounds this narrative in many of his score markings. The opening scherzo section is marked "Lifting off..." and the first laptop trigger is labeled "spaceship booting up." Various triggers are given programmatic titles throughout the piece: "radio static," "hydraulic doors," "spaceship accelerating," "over and out signal" (see Example 1).
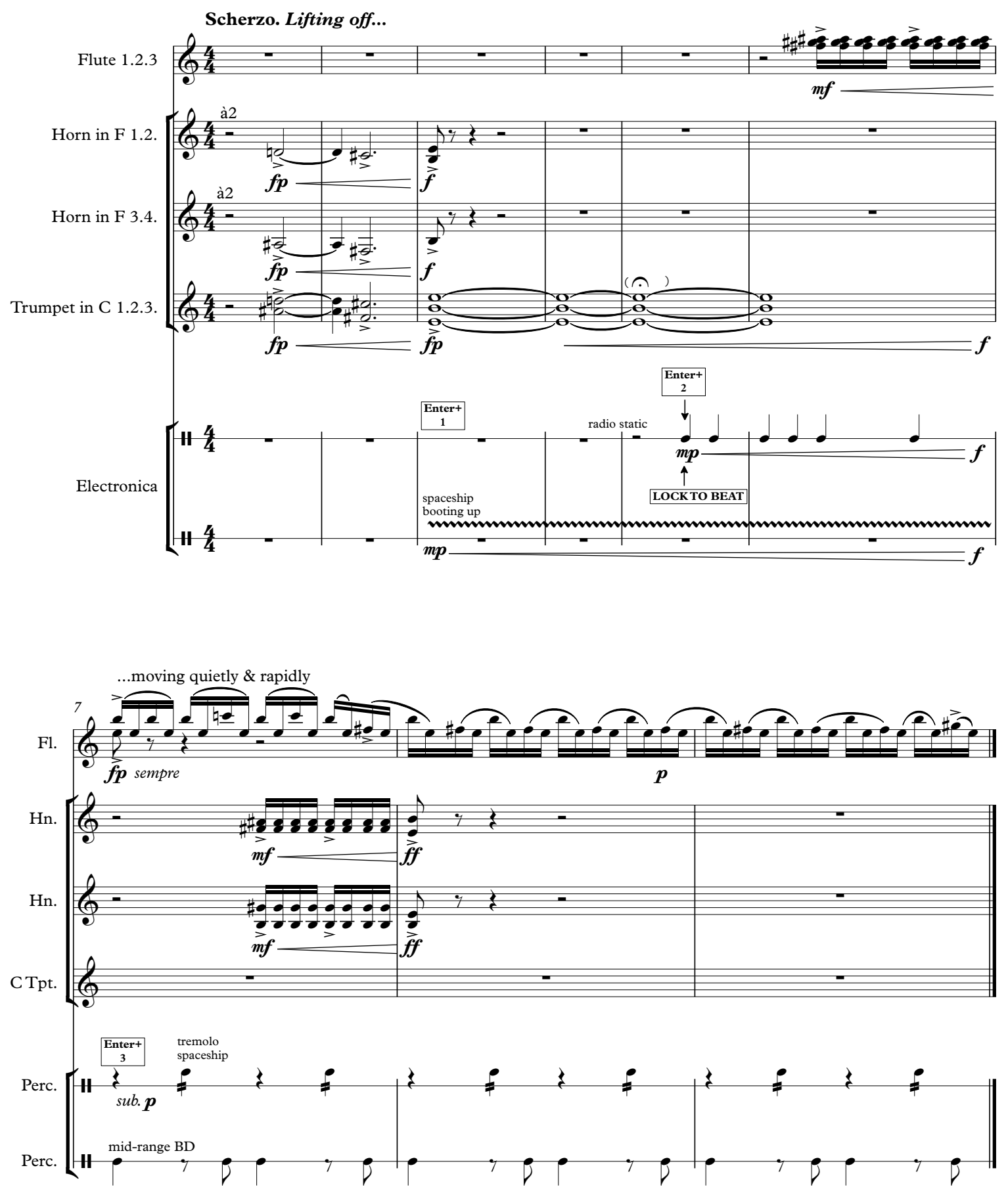

Example 1: Mason Bates, Mothership, mm. 1-9 (flute, horn, trumpet, electronica only) 
The piece opens with a three-measure brass fanfare, made up of swelling fourths and fifths, that herald the heroic takeoff of the spaceship. In measure five, the drum machine enters; from that point on, the piece is rarely without the drum machine's regular "four on the floor" beat pattern. In approving reviews of Bates, as well as in his own self-presentation, his dual experience as a classical composer and DJ is often highlighted. Bates continues to perform DJ gigs in addition to his compositional work and live performances with symphony orchestras. Rental fees for Bates's scores cover not only the scores themselves but also a package of samples and triggers meant to be performed on a computer; Bates plays these sounds live in many performances of his own works. Maintaining his image as a DJ is clearly important to his brand as a genre-hopping technological adept. In many ways, his evocation of electronica DJing (hunching intently over his computer while bobbing his head with the beat) is a fairly tepid, stripped-down version of the art form; examine Bates's performance at the Sydney Opera House alongside any video of Skrillex or any other high-level electronic music producer performing live, and it becomes clear that Bates's tame, regular beats and periodic electronic noises are not meant to appeal to hardcore techno fans.

Nor is the piece meant to appeal to hardcore classical music fans, however. As it does with certain obvious markers of techno music, Mothership similarly evokes many time-honored clichés of a certain type of orchestral music, without really being "classical music" in the sense of the term most scholars and practitioners would use. The opening horn fanfare heroically describes the spaceship taking off; sudden transitions into modal collections let us know we are entering an exotic, foreign planet; there is no motivic, thematic, harmonic, or structural complexity of any kind and yet it is also worlds away from the kind of hypnotic simplicity manifested by early minimalism; the piece's governing characteristic is a nonstop driving forward motion punctuated by great blasts of timpani and cymbals. I would argue that the orchestral tradition Bates is most aligned with is not that of Berlioz and Liszt but rather of John Williams and Howard Shore. By using simplified tropes from both techno and orchestral art music, Bates can appear cool and edgy while also seeming to further the practice of old-fashioned concert music. This combination has made Bates a sought-after composer for traditional music institutions, who hope he will help them appeal to wider audiences than classical music-especially music associated with the modernist tradition-normally does.

The most celebrated feature of Mothership is Bates's inclusion of four breaks in which designated musicians-representing entities from different alien planets-“dock" with the mothership, and take solos. ${ }^{37}$ There are four Docking Episodes in total; two are marked "Rhythmic" and two "Lyrical." Each episode is preceded by the "docking signal," a reverberating beep that heralds a pause in the mothership's churning forward motion. The soloists at the Sydney performance had also competed for their slots via uploaded audition videos, and the ones chosen represented Bates's and the project organizers' commitment to diversity of both the multicultural and the musical-generic varieties. The soloists (Paulo Calligopoulos, Ali Bello, Su Chang, and John Burgess) were from four different countries, and played, respectively, a distorted electric guitar, a violin, a Chinese guzheng, and an electric bass. Each of the soloists is also conventionally attractive and charismatic. When I asked YouTube Marketing Director Ed Sanders how the soloists were chosen, he told me that they needed to manifest "the minimum level of quality and chops, but also, you know, personality," and added that "that's something that I think

\footnotetext{
${ }^{37}$ Bates wrote solos in the score for Mothership, but he notes that solos can be improvised whenever a performer is comfortable doing so. He includes lead sheets in the back of the score, giving harmonic information and suggested groups of notes to improvise around in each solo section.
} 
technology has helped bring to the space." By this he meant that since the YTSO organizers did not do blind auditions, but rather examined musicians' appearance in uploaded videos, they were able to choose soloists based on looks and charisma as well as technical skill.

In interviews about Mothership, Bates expresses excitement about "bringing improvisation back into the world of classical music," and foregrounds this element of Mothership as a major innovation. ${ }^{38}$ He was also excited about incorporating soloists from diverse musical backgrounds-in his video advertising the auditions, he repeatedly stated that "even if you aren't a classical musician, we still need to hear from you." After the first performance, at Carnegie Hall, the organizers posted a mashup of audition videos they had received; many videos featured unusual instruments like kazoo, toy piano, kitchen mixing bowls, and melodica.

Throughout the YTSO performance, however, it was not always clear what precisely "classical music" meant; Bates and Tilson Thomas used the phrase to indicate many different kinds of music from multiple countries and time periods. The didgeridoo improvisation was presented as classical music based on the fact that the didgeridoo is "ancient," for example. In fact, in the YTSO project, and especially in his discussions of Mothership's solos, we can see that for Bates, "classical music" is not a descriptor of any given repertoire, style, or set of instruments; rather, it is a word meant to evoke noble, universal values. In the popular imagination, classical music is associated with elitism and ancient history, and as such it might seem to have little to do with the populism of neoliberalism, which spurns all hide-bound tradition and valorizes the new. On the other hand, a whiff of eternal grandeur still clings to the term "classical," which, in the late eighteenth century, began being used to indicate objects or concepts that were perceived as timeless and morally righteous. This sense of timeless virtue is what Bates primarily wishes to convey when he uses the term "classical music." It is also this sense of the term that is easily marshaled in the service of capitalist values. ${ }^{39}$

By using only English, and by asserting that in spite of their geographical diversity all these players were united by their identical love of the internet and the concert repertoire of eighteenth- and nineteenth-century Europe; by minimizing the fact that the musicians were not paid; and by constantly praising the "inherently democratic" nature of the internet itself, the YTSO project effectively mythologized the dominant economic theories of our time-theories that have become rooted in our moral beliefs about freedom, diversity, individuality, and choice. In the project's rhetoric, which was overseen and developed by Google, "classical music" stands in for capitalism as the universalizing force that brings us all together.

\section{The Rise of Exotic Computing and the Internet of Everything}

I would now like to return to a closer examination of The Rise of Exotic Computing, the piece with which I opened this study. I find the combination of Bates's music with Cisco's corporate slogan meaningful, in light of his established optimism about innovation, YouTube, and tech entrepreneurship. Like Mothership, Garages of the Valley and The (R)evolution of Steve Jobs, Bates's Exotic Computing is a

\footnotetext{
${ }^{38}$ See Bates's introductory video—projected during the YTSO concert in Sydney (URL above)—in which he explains Mothership.

${ }^{39}$ See David Ferris, Silent Urns: Romanticism, Hellenism, Modernity (Stanford: Stanford University Press, 2000). Michael Long specifically addresses the ethical dimension of the term "classic" in Beautiful Monsters: Imagining the Classic in Musical Media (Berkeley: University of California Press, 2008), 31.
} 
programmatic work that aurally represents a specific technological innovation. And, like the YTSO performance in Sydney, the performance of the piece at the 2014 Cisco partners summit also worked to establish a specifically neoliberal worldview_and thus, endear Bates and his music to the tech billionaires who espouse that worldview - by essentially propagating a corporate marketing strategy within a set of inspirational common-sense beliefs about togetherness and the virtuous grandeur of classical music.

In an interview about Exotic Computing that took place in the Chicago Symphony Orchestra's server room, Bates eerily invokes the central tenet of capitalism when he says that "the idea of the piece is to accumulate." Indeed, the short, single-movement work is meant to sound like "a self-replicating synthetic computer," which accumulates lines of code without human intervention. The sinfonietta is built on Bates's characteristically springy deployment of tiny, tight motives (usually consisting of only three or four notes in a very small range), which are nimbly traded from instrument to instrument atop a pulsing foundation of repeated single notes also traded between instruments. As with most of Bates's music, the piece is very upbeat, and foregrounds an extreme rhythmic regularity aided by the drum machine, which, while often heavily syncopated, nonetheless provides a regular driving pulse. ${ }^{41}$

The work opens with a slowly building, 70-measure introduction that establishes both the conceptual framework and the main motivic content for the rest of the piece. Several instruments begin by trading off a quick $32^{\text {nd }}$-note pulse on a single note, which is alternated with a single-note triplet. As this fast repetition is passed from instrument to instrument, we slowly get a sense of an overlapping pulse, as the straight $32^{\text {nd }}$-note figure in one instrument is heard against the triplet in another. We also hear a ghostly echo of one of the main melodic motives that will organize the rest of the piece-a figure that rocks back and forth in eighth notes, against syncopated single notes or chords in other instruments (see Example 2). The "accumulatory" premise of the work is established very quickly, as these tiny traded figures combine to create great waves of sound that roll across the ensemble, building and subsiding, until new waves take their place. The effect of this introduction is of the orchestra slowly gathering its forces, finding its footing, and establishing lines of communication between the individual instruments, as they practice trading short figures back and forth.

As the ensemble enters the main body of the piece, some similarities with early repetitive, pulsepattern minimalism become evident. Like many young composers working in the U.S. today, Bates often relies on structural ideas drawn from early New York minimalism. His "accumulatory" use of small motives sounds like the early "gradual process" works of Steve Reich and Philip Glass-major foundations for much of the mainstream art music composed in the U.S. today. In The Rise of Exotic Computing I hear prominent echoes of Music for 18 Musicians, as the piece moves in a modular fashion through soundscapes based on single, simple, repetitive motives. The texture of the two ensembles is also quite similar; both incorporate piano and marimba into a small conventional orchestra, although there are no human voices in

\footnotetext{
${ }^{40}$ Video interview with Mason Bates, CSO Sounds and Stories (September 24, 2014), http://csosoundsandstories.org/masonbates-on-the-rise-of-exotic-computing/.

${ }^{41}$ Again, my discussion is based on the score (Aphra Music, 2014). The Rise of Exotic Computing is scored for a flute, oboe, Bb clarinet, bassoon, F horn, $\mathrm{C}$ trumpet, harp, piano, violin, viola, cello, bass, and a single percussionist who alternates between marimba, glockenspiel, and cymbals. There is also an "electronica" part consisting of a performed drum machine beat (mostly notated) and trigger indications for various synthesized sounds. The piece has not been officially recorded; there are currently two unofficial ways to hear it, which must be combined to get a (still incomplete) aural sense of the work. The Las Vegas Youth Orchestra performance at the Cisco Partner Summit is available on YouTube (https://www.youtube.com/watch?v=stPjtLh3h-A); however, for this performance Bates (who also conducted) made quite a few edits and cuts, at two points skipping several pages of the score, and cutting the entire introduction to the piece. However, the introduction alone is available in snippet-form on his website (www.masonbates.com/music).
} 
Bates's work (and, of course, no drum machine or laptop triggers in Reich's). But, where Reich allows his modules to spin out slowly over great lengths of time, Bates usually only spends a few measures exploring a given figure or key area, before crescendoing and climaxing into a new section.

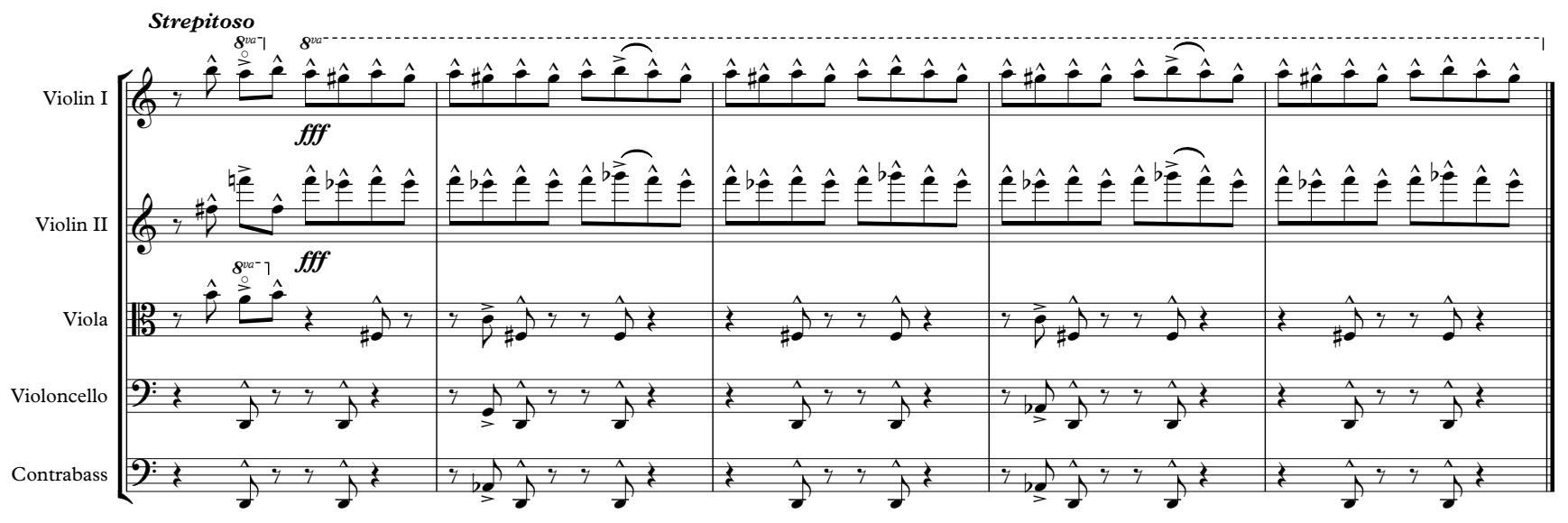

Example 2: Mason Bates, The Rise of Exotic Computing, mm. 61-65 (strings only)

So, whereas on its surface, Exotic Computing seems to evoke the compositional technique of early Reich, it does so with very different affective goals. Reich trades motives and changes chordal content slowly, so slowly that harmonic movement or the entrances/exits of instruments can sometimes go unnoticed. In Exotic Computing, due to the much shorter length of each module, the motivic interplay between the instruments is much more obvious, as there is almost no time spent on smooth and slow transitions. Thus, the overall effect is agitated, super dramatic, and somewhat frenetic, whereas I experience 18 Musicians as hypnotic. In every section of the piece, tiny motives are passed off after only a few bars, and the piece builds connectivity so quickly that it is often hard to follow a given motive as it leaps around.

In Robert Fink's study of American minimalism, he argues that whereas critics and composers positioned early pulse-pattern minimalism as music that resisted commodification, in actuality the music is fully imbricated within the type of meaningless repetition that became the vehicle for consumer capitalism in the postwar United States. For Fink, the early minimalism of composers like Reich is organized by rhythmic flow, and teaches its listeners to "surf" the waves of repetition characterizing the advertising language and much of the media content of the $1960 \mathrm{~s}^{42}$

I see many potentially fruitful possibilities for musicological discussions of the "post-minimalist" tendencies of some of the young composers working most successfully in the United States today. Perhaps the frenetic, jarring transitions between the repetitive modules of Exotic Computing have something to tell us about the way repetition functions in contemporary society, and about the way subjectivity has been conditioned by new forms capitalism has taken since the 1970s. The frantic passing around of motives from instrument to instrument in The Rise of Exotic Computing may evoke the increasingly fast cycling of

${ }^{42}$ Robert Fink, Repeating Ourselves: American Minimal Music as Cultural Practice (Berkeley: University of California Press, 2005), 141. 
the stock market, for example, in which toxic assets are passed quickly from investor to investor like hot potatoes. Bates intended his motivic accumulation to evoke the self-replication of computer code, but this idea also brings to mind a central process of capitalism, by which capital replicates and accumulates through no labor on the part of its owner. Additionally, we may hear this piece as reflecting the neoliberal imperative of flexibility, under which citizens must become comfortable moving constantly between disparate tasks, jobs, and labor contracts. Within the doctrine of flexibility, repetitive tasks or stable, consistent jobs become figured as stifling, and as placing untenable limits on personal freedom. Given this devaluation of long-term stability, perhaps it makes sense that contemporary audiences find Bates's frenetic, jarring transitions between musical modules so compelling.

Exotic Computing's sonic imitation of digitally-aided connectivity-represented by the way small motives work frantically to link together every member of the orchestra as quickly as possible-was the perfect sound to cap the Cisco partner summit in Las Vegas, an event characterized by talk of almost nothing but instantaneous connectivity. In 2014, Cisco began aggressively capitalizing on the concept of "The Internet of Everything," which it appropriated as an advertising slogan. The term is meant to denote what the world will look like in the near future, when every aspect of personal, social, and professional life across the globe will have been digitized and connected via the internet. As a multinational corporation specializing in networking technologies, Cisco has much to profit from the total global connectivity the Internet of Everything (IoE) will require.

In promoting the IoE, Cisco officials applaud the universalizing potential of Internet connectivity, Big Data, and the surveillance state. ${ }^{43}$ Massive databases of information are required to implement the IoE; accordingly, most of the examples of the IoE that Cisco officials describe rely on the unspoken assumption that one day soon there will be cameras, satellites, sensors, and other tracking devices watching all people at every moment and conveying a constant stream of data about them-their activities, their emotions, their spending habits, their physical bodies- to the cloud, where Cisco's various corporate holdings and partner firms will sort and analyze it using Cisco technologies. Cisco CEO John Chambers gave an interview to Information Week at 2014's international Consumer Electronics Show in which he described the IoE's revolutionary potential to change the lives of citizen-consumers all over the world. He suggested for example that embedded sensors in a home's garbage receptacles could "allow officials to see how full a can is," as well as whether hazardous materials are inside, and noted that this data could be analyzed to determine when garbage companies should pick up waste, thus solving traffic problems caused by regular pickup routes (intermittent garbage collection would also solve the problem of paying benefits to full-time garbage collectors). He discussed smart-clothing that could tell its wearers when they were getting sick as well as alert their doctors and pharmacies, and smart-cars that could communicate with their passengers' smart-homes and -workplaces. He added that ideas like this will lead to billions in savings and allow consumers to live to one hundred years of age. ${ }^{44}$

Cisco's marketing materials work to present the absolute totalization of the IoE as utopian rather than frightening. One of the most widely-circulated advertisements Cisco has produced shows a soothing series of actions that lead to other actions, instigated or aided by an overriding connected network that

\footnotetext{
${ }^{43}$ For further reading on neoliberalism and Big Data, see Ronald E. Day, Indexing It All: The Subject in the Age of Documentation, Information, and Data (Cambridge: MIT Press, 2014).

${ }^{44}$ Michael Endler, “CES 2014:Cisco's Internet of Everything Vision,” Information Week (January 11, 2014), http://www.informationweek.com/strategic-cio/executive-insights-and-innovation/ces-2014-ciscos-internet-of-everythingvision/d/d-id/1113407.
} 
benevolently observes every person in every moment: a fully-automated house brews coffee; which wakes up a man; who gets into his self-driving car; which communicates with his workplace when it's time for the building's door to open for him, etc. On top of this visual pattern of technologically-mediated actions and reactions, an amused masculine voice intones a reassuring stream-of-consciousness text reminiscent of the soothing patterns of children's literature:

This is the cat that drank the milk that let in the dog that jumped on the woman who brewed the coffee that woke the man who was late for work and drove the car that found the parking spot that alerted the door that opened the control room that secured the data that directed the turbines that powered the sprinklers that watered the grass that fed the cow that made the milk that went to the store that reminded the man to buy the milk that was poured by the girl who loved the cat who drank the milk. The Internet of Everything is changing everything. Cisco. Tomorrow starts here. ${ }^{45}$

The Rise of Exotic Computing, with its dramatic musical depiction of digital connectivity and data accumulation, and its inspirational example of how musical performance allows people to be "amazing together," was thus the perfect choice for Cisco's sponsored content at the partner summit, and the accompanying video aptly reiterated the same kind of benevolent total connectivity advocated for by the company, its partners, and its advertising materials. Although "amazing together" was the slogan of the partner summit, and thus was not a concept that originated from Bates himself, it nonetheless is an apt descriptor of the affective intent of much of Bates's work. "Amazing together" would have been the perfect tag for the YTSO project, for example ${ }^{46}$, which so insistently foregrounded the beauty of global collaboration and the breaking down of cultural boundaries made possible by the internet, but even in Bates's other works, as I have demonstrated, we can often see a similar sort of optimistic valorization of some of the facts of life under neoliberalism.

\section{Classical Music and Neoliberal Contradictions}

American arts journalists, performers, and composers routinely discuss the necessity of "dragging" classical music "into the real world," by which they mean the competitive entertainment marketplace. Mason Bates's success is one example of a composer being rewarded for subscribing to this imperative. Other artists are even more vocal in espousing the necessity of classical music becoming more financially competitive. In an interview with New Music Box's Molly Sheridan, the young Brooklyn-based composer Judd Greenstein spoke at length about his belief that classical music needs to enter the real world, saying that he does not believe there is any work that needs to be "sheltered" from the marketplace. ${ }^{47}$ Prominent musical activist Greg Sandow (who maintains a well-read blog on Arts Journal and teaches classes on musical entrepreneurship at Juilliard) argues that classical concerts must attract younger ticket-buyers by incorporating new technology_for example, video screens showing tweets from audience members during performances - and that orchestras and opera houses must begin catering to the newly-omnivorous music-consuming public. ${ }^{48}$

\footnotetext{
${ }^{45}$ This advertisement is widely available on YouTube (https://www.youtube.com/watch?v=5Jxo7AGZmMw).

${ }^{46}$ The YTSO's actual tagline was "play your part."

${ }^{47}$ Molly Sheridan, 'Judd Greenstein-A World of Difference,' New Music Box (January 17, 2011), http://www.newmusicbox.org/articles/judd-greenstein-a-world-of-difference/.

${ }^{48}$ Sandow elaborates on these themes and ideas regularly on his blog, Artsfournal.com/sandow. See also John von Rhein's article about Sandow in the Chicago Tribune, "What can be done to make classical music more relevant to today's culture? Ask
} 
Like the Chicago School economists of the 1960s, these artists and critics unproblematically envision the free market as a liberatory force for positive social change, and they routinely counterpose economically-successful new music against the enervating academicism of earlier twentieth-century composition. ${ }^{49}$ The necessity for classical music to compete in the entertainment marketplace is presented as an avenue toward individual freedom for performers, whose liberty and creativity have been constricted by musicians' unions and the staid programming of older institutions. Ronen Givony, the founder of (Le) Poisson Rouge (the New York new music venue, which books an eclectic mix of classical, rock, hip hop, and experimental pop music), told me that he has never applied for grants for his projects because of his desire to remain "independent." Saying that he believes in paying artists fairly, charging a fair price for tickets, and putting on a good show, Givony added "You know, you tell people in the rock world how classical music works and they stare at you in disbelief. Not only is the money what it is, but the question of breaking even is never even broached." ${ }^{50}$ This horror of classical music's supposed inability to generate revenue is common amongst the new breed of artists and programmers currently defining the American classical music scene. Givony said that remaining independent-that is, dependent on ticket sales rather than institutional or government grants-liberates his projects from "the rising and falling tides of the music economy." Although the tastes of the ticket-buying public surely represent the changing tides of the music economy just as well as - if not better than — the vagaries of state funding, this contradiction can go unnoticed within neoliberal ideology, which takes the liberatory potential of entrepreneurial hustling for granted. ${ }^{51}$

In another contradictory rhetorical trend, commentators regularly present entrepreneurial flexibility and innovation as forces for the greater good even as the destructive, antisocial nature of these processes is also taken for granted. Discussing the changing perception of classical music in the U.S., Judd Greenstein said that there is no music that needs to be "sheltered" from the marketplace, adding that "the truth is that things are always disappearing, though, and things are always changing. We can't live in a conservative world; we have to live in a dynamic world." 52 Here, Greenstein uncritically accepts the instability created by neoliberal business policies, in which the relentless pursuit of innovation leads to ever-faster turnover of fashions, trends, neighborhoods, jobs, and even whole industries. The flutist Claire Chase has articulated similarly contradictory beliefs. Chase, who founded the International Contemporary Ensemble, won a MacArthur "genius" grant in 2012 for her "arts entrepreneurship" activism. In a now-infamous address at Northwestern's Bienen School of Music, Chase enjoined the graduating class to fulfill their "destiny" of becoming musical entrepreneurs, saying that this will build "better organizations and stronger communities." However, in the same speech, she insists "I'd love for every single one of you to put me out

\footnotetext{
young musicians" (April 29, 2010).

${ }^{49}$ See for example the young, Yale-trained composer Missy Mazzoli’s fierce criticism of "academic" music and musical institutions, in Stephen Brooks, "Missy Mazzoli has a different take on classical music_and people are listening," The Washington Post (May 7, 2011).

${ }^{50}$ Ronen Givony, phone interview with the author, April 21, 2012.

${ }^{51}$ Ilana Gershon discusses the atomization caused by this kind of neoliberal rationality, which insists that each citizen is solely responsible for their own success or failure. Under neoliberalism, as Gershon puts it, citizens must think of themselves not as coherent "selves" but rather as "bundles of skills" to be managed and marketed like a business. ("Neoliberal Agency," Current Anthropology 52, no. 4 (August, 2011), 537-555). See also Wendy Brown's statement, that neoliberal subjects become "rational, calculating creatures whose moral autonomy is measured by their capacity for 'self-care'-the ability to provide for their own needs and service their own ambitions." ("Neoliberalism and the End of Liberal Democracy," 42). For a booklength study of self-care under neoliberalism see Arlie Russell Hochschild, The Commercialization of Intimate Life: Notes from Home and Work (Berkeley: University of California Press, 2003).

${ }^{52}$ Molly Sheridan, "Judd Greenstein-A World of Difference."
} 
of business. Then I will know that I have done my job.” In a New York Times article about Chase, Anthony Tommasini calls this statement "empowering," and says that Chase makes "the most positive case [he has] ever heard for the new entrepreneurship." ${ }^{33}$ It is difficult to see how deliberately attempting to put one another out of our jobs builds stronger communities, but this is the contradictory logic that becomes naturalized under neoliberalism. ${ }^{54}$

It is significant that Bates, with his classical pedigree on the one hand and his glorification of hightech entrepreneurialism on the other, has attained such relatively mainstream fame and institutional success at a time when classical music in the United States is widely considered to be more imperiled than ever before. ${ }^{55}$ In fact, although he is presented as revolutionary, in many respects his career, compositions, and stated beliefs actually hew closely to the dominant ideals of the most powerful people in our society. Indeed, this quality of appearing revolutionary while actually serving the needs of capital is a major reason the tenets of neoliberalism have found such a foothold in the U.S. consciousness. ${ }^{56}$ Because of the way neoliberal rhetoric champions deregulation and the destruction of labor power by evoking a utopian vision of global freedom and equality, it is easy for it to masquerade under the guise of social progressivism.

There is a long precedent for the kind of technology-oriented musical-corporate connections I have explored in this article: in the previous generation, institutions like IRCAM and the BBC Radiophonic Workshops similarly constructed a rhetoric privileging scientific musical research and technological innovation that appealed to power, and that secured funding and prestige for new music in a changing world.$^{57}$ Even from its earliest moments, "computer music" has had strong ties to powerful industry; the first computer-generated music was made via a technology invented by a Bell Telephone Laboratories researcher who was trying to convert audio signals to digital information in order to automate the tasks performed by telephone operators. ${ }^{58}$

What has changed since the 1960s is the form power has taken. IRCAM, for example, is statefunded, and its founding was part of the French government's nationalistic plan for rebuilding its image in the wake of the social turmoil of $1968 .^{59}$ By contrast, the power that some of today's most successful and

\footnotetext{
${ }^{53}$ Anthony Tommasini, "Claire Chase Invites Young Musicians to Create New Paths," The New York Times (December 26, 2013). Chase's address to the Bienen School is viewable on the school website: http://www.pickstaiger.org/video/2013-bienenschool-music-convocation-address-claire-chase.

${ }^{54}$ See Andrea Moore, "Neoliberalism and the Musical Entrepreneur," cited above, for a much more in-depth study of Chase and musical entrepreneurship.

${ }^{55}$ Some of the canonical texts in the debate concerning classical music's ongoing demise are: Norman Lebrecht, Who Killed Classical Music? Maestros, Managers, and Corporate Politics (New York: Birch Lane Press, 1997); Julian Johnson, Who Needs Classical Music? Cultural Choice and Musical Value (Oxford: Oxford University Press, 2002); Lawrence Kramer, Why Classical Music Still Matters (Berkeley: University of California Press, 2009). See also Mark Vanhoenacker's recent article “Requiem: Classical Music in America is Dead," Slate.com (January 21, 2014); and William Robin's retort, "The Fat Lady is Still Singing," New Yorker.com (January 29, 2014).

${ }^{56}$ In Constructions of Neoliberal Reason, for example, Jamie Peck devotes a chapter to Richard Florida, an urban studies scholar who became a sought-after urban development consultant upon the publication of his 2002 book The Rise of the Creative Class. Florida claimed that "creative capital" represented the new frontier of capital accumulation, and Peck notes that while this idea was packaged as revolutionary, progressive, and even anti-corporate (due to Florida's privileging of individual creativity over older business models), his policies actually work entirely within the grain of existing, neoliberal development agendas that favor corporate investment and promote gentrification and the criminalization of the poor. Indeed, Peck argues, cities across America would not have hired Florida were this not the case.

${ }^{57}$ See Georgina Born, Rationalizing Culture: IRCAM, Boulez, and the Institutionalization of the Musical Avant-Garde (Berkeley: University of California Press, 1995); and Louis Niebur, Special Sound: The Creation and Legacy of the BBC Radiophonic Workshop (Oxford: Oxford University Press, 2010).

${ }^{58}$ See Richard Taruskin, The Oxford History of Western Music, vol. 5 (Oxford: Oxford University Press, 2005$), 495$.

${ }^{59}$ In Rationalizing Culture, Born provides an in-depth explanation of IRCAM as a nation-building project, and a detailed explanation of its sources and amounts of funding.
} 
widely-acclaimed musical innovations-like those of Mason Bates-are meant to appeal to is corporate power, the power of private enterprise, which is a power that neoliberalism deliberately counterposes against that of the oppressive state and its obsolete nationalisms.

I have sought to use Mason Bates as a case study for demonstrating that classical music in contemporary U.S. practice is becoming imbued with a neoliberal value system that privileges—and even demands-constant technological innovation. Although I would not suggest that they have necessarily done so consciously, it is clear that artists, institutions, and journalists have adopted this value system in an effort to make classical music relevant within the dominant discourse of American society.

We can see similar scrambles currently going on in many other "unprofitable" spheres of artistic and intellectual endeavor, all of them linked by their efforts to make their products ascribe to the nowdominant logic of the free market. In a harrowing essay critiquing the rise of Digital Humanities, for example, three professors of literature and media studies investigate trends in higher ed, observing many of the ideological and rhetorical moves I have identified in this article. Critiquing it as a symptom of the "neoliberalization" of the American university, the authors demonstrate that the rhetoric promoting Digital Humanities insists that quantitative, computer-aided data management is the future of all humanistic scholarship, and that "computer use is an end in itself." ${ }^{60}$ On the one hand, the meteoric rise of Digital Humanities in the American university system represents scholars' desperate attempt to legitimize the Humanities in the eyes of neoliberal administrations, which value only academic labor that is directly saleable in the marketplace or to corporations. However, the association of the Humanities with the values of the dominant financial elite does more than merely eke out a new market niche for these scholars; it also serves the university's neoliberalizing agenda, by siphoning funding away from critical, interpretive, and politically-engaged scholarship, and, thus, helping to make traditional academic labor ever-more precarious and contingent. ${ }^{61}$

Similarly, the merger of classical music with the neoliberal value of innovation is not only beneficial to classical music practitioners who are trying to make a living in an economic landscape increasingly hostile to the arts; it also helps to further entrench neoliberal ideology into the common-sense worldviews of those practitioners, and in more concrete terms, it creates new streams of revenue for corporate capitalism, just as IRCAM's promotion of musical research generated new products for the military and the marketplace. ${ }^{62}$

The neoliberal economic framework for understanding contemporary classical music in the United States is just beginning to be established. In this article, I have attempted to assess some of the ways new music might be heard as sonically bearing the marks of the kinds of cultural transformations U.S. life has undergone in the past few decades. By combining economic and cultural discussion with interpretations of musical sounds, I have tried to reveal some of the ways new music-its composition, performance, and

\footnotetext{
${ }^{60}$ Daniel Allington, Sarah Brouillette, and David Golumbia, "Neoliberal Tools (and Archives): A Political History of Digital Humanities," LA Review of Books (May 1, 2016).

${ }^{61}$ In a forthcoming article, the musicologist David Blake investigates a similar trend in higher ed, namely, the increasing imperative that all work must be "interdisciplinary." Blake uses Bourdieu's "omnivore theory" to dissect interdisciplinarity, arguing that as an academic value it has been conditioned by neoliberalism ("Musicological Omnivory in the Neoliberal University").

${ }^{62}$ Pierre-Michel Menger notes that these new "market shelters" for electronic and computer music were obviously beneficial for the composers and programmers who were able to obtain positions within them. But, more insidiously, Menger argues that the funding institutions that supported these "parasitical organisms" did so because the research they produced could have "considerable applications in the fields that are economically or even militarily essential" ("Technological Innovations in Contemporary Music," Fournal of the Royal Music Association 114, no. 1 (1989), 92-101).
} 
reception-has been shaped by assumptions drawn from neoliberal dictums. More importantly, I have attempted to argue that when classical music (or any other beloved art form or practice) is pragmatically re-oriented to align with hegemonic values, it contributes to the propagation of those values throughout society. The kinds of musical glorifications of corporate business strategies that I have identified in this article help to promote labor insecurity, market rationality, and globalization as liberatory forces for the general good, and thus they contribute to our increasing inability to envision alternatives to capitalism.

\section{References}

Allington, Daniel, Sarah Brouillette, and David Golumbia. "Neoliberal Tools (and Archives): A Political History of Digital Humanities.” LA Review of Books (May 1, 2016).

Applegate, Celia. "How German Is It? Nationalism and the Idea of Serious Music in the Early Nineteenth Century." $19^{\text {th }}$-Century Music 21, no. 3 (1998): 274-96.

Attali, Jacques. Noise: The Political Economy of Music. Translated by Brian Massumi. Minneapolis: University of Minnesota Press, [1985] 2006.

Boltanski, Luc, and Eve Chiapello. The New Spirit of Capitalism. Translated by Gregory Elliott. London: Verso, 2005.

Born, Georgina. Rationalizing Culture: IRCAM, Boulez, and the Institutionalization of the Musical Avant-Garde. Berkeley: University of California Press, 1995. https://doi.org/10.1525/california/9780520202160.001.0001.

Brown, Wendy. Edgework: Critical Essays on Knowledge and Politics. Princeton: Princeton University Press, 2005.

Day, Ronald E. Indexing It All: The Subject in the Age of Documentation, Information, and Data. Cambridge: MIT Press, 2014.

Federici, Silvia. Caliban and the Witch: Women, the Body, and Primitive Accumulation. New York: Autonomedia, 2004.

Ferris, David. Silent Urns: Romanticism, Hellenism, Modernity. Stanford: Stanford University Press, 2000.

Fink, Robert. Repeating Ourselves: American Minimal Music as Cultural Practice. Berkeley: University of California Press, 2005.

Florida, Richard. The Rise of the Creative Class, and How It's Transforming Work, Leisure, Community and Everyday Life. New York: Basic Books, 2002.

Friedman, Milton. Capitalism and Freedom. Chicago: University of Chicago Press, 1962.

Fuchs, Christian. Reading Marx in the Information Age. New York: Routledge, 2016.

Gershon, Ilana. "Neoliberal Agency." Current Anthropology 52, no. 4 (August 2011): 537-55. https://doi.org/10.1086/660866.

Gordon, Avery F. and Christopher Newfield, eds. Mapping Multiculturalism. Minneapolis: University of Minnesota Press, 1996.

Hale, Charles R. "Neoliberal Multiculturalism: The Remaking of Cultural Rights and Racial Dominance in Central America." PoLAR 28, no. 1 (May 2005): 10-28. https://doi.org/10.1525/pol.2005.28.1.10.

Harvey, David. A Brief History of Neoliberalism. Oxford: Oxford University Press, 2005. 
Hayek, Friedrich von. The Road to Serfdom. Chicago: University of Chicago Press, 1944.

Hochschild, Arlie Russell. The Commercialization of Intimate Life: Notes from Home and Work. Berkeley: University of California Press, 2003.

Johnson, Julian. Who Needs Classical Music? Cultural Choice and Musical Value. Oxford: Oxford University Press, 2002. https://doi.org/10.1093/acprof:oso/9780195146813.001.0001.

Jones, Daniel Stedman. Masters of the Universe: Hayek, Friedman, and the Birth of Neoliberal Politics. Princeton: Princeton University Press, 2012.

Kramer, Lawrence. Why Classical Music Still Matters. Berkeley: University of California Press, 2009.

Lal, Deepak. Reviving the Invisible Hand: The Case for Classical Liberalism in the Twenty-First Century. Princeton: Princeton University Press, 2006.

Lebrecht, Norman. Who Killed Classical music? Maestros, Managers, and Corporate Politics. New York: Birch Lane Press, 1997.

Levidow, Les. "Neoliberal Agendas for Higher Education." In Neoliberalism: A Critical Reader, edited by Alfredo Saad-Filho and Deborah Johnston, 156-62. London: Pluto Press, 2005.

Long, Michael. Beautiful Monsters: Imagining the Classic in Musical Media. Berkeley: University of California Press, 2008.

Melamed, Jodi. "The Spirit of Neoliberalism: From Racial Liberalism to Neoliberal Multiculturalism.” Society Text 89 (Winter 2006): 1-25. https://doi.org/10.1215/01642472-2006-009.

Menger, Pierre-Michel. "Technological Innovations in Contemporary Music." Journal of the Royal Music Association 114, no. 1 (1989): 92-101. https://doi.org/10.1093/jrma/114.1.92.

Mirowski, Philip, and Dieter Plehwe, eds. The Road from Mont Pèlerin. Cambridge: Harvard University Press, 2009. https://doi.org/10.4159/9780674054264.

Moore, Andrea. "Neoliberalism and the Musical Entrepreneur." Journal of the Society for American Music 10, no. 1 (2016): 33-53. https://doi.org/10.1017/S175219631500053X.

Mylonas, Yiannis, "Amateur Creation and Entrepreneurialism: A Critical Study of Artistic Production in Post-Fordist Structures.” tripleC: Communication, Capitalism, and Critique 10, no. 1 (January 2012): 111.

Niebur, Louis. Special Sound: The Creation and Legacy of the BBC Radiophonic Workshop. Oxford: Oxford University Press, 2010. https://doi.org/10.1093/acprof:oso/9780195368406.001.0001.

Peck, Jamie. Constructions of Neoliberal Reason. Oxford: Oxford University Press, 2010. https://doi.org/10.1093/acprof:oso/9780199580576.001.0001.

Pippen, John. "Toward a Postmodern Avant-Garde: Labour, Virtuosity, and Aesthetics in an American New Music Ensemble.” PhD diss., University of Western Ontario, 2014.

Robin, Will. "A Scene Without a Name: Indie Classical and American New Music in the Twenty-First Century.” PhD diss., University of North Carolina, Chapel Hill, 2016.

Schumpeter, Joseph. Capitalism, Socialism, and Democracy. New York: Harper \& Brothers, 1942.

Taylor, Timothy D. Music and Capitalism: A History of the Present. Chicago: University of Chicago Press, 2016. https://doi.org/10.7208/chicago/9780226312026.001.0001.

Vernallis, Carol. Unruly Media: YouTube, Music Video, and the New Digital Cinema. Oxford: Oxford University Press, 2013. https://doi.org/10.1093/acprof:oso/9780199766994.001.0001. 


\begin{abstract}
We are all connected...one universe...one planet...one ecosystem...thriving as one network...working with one purpose...we are... amazing together
\end{abstract}

These sentiments, accompanied by images of dolphins, forests, cell-phone towers, and outer space, were projected onto screens encircling the Las Vegas Youth Orchestra as it performed at the 2014 partner summit of Cisco Systems, Inc., a multinational conglomerate specializing in networking technology. The music on offer was The Rise of Exotic Computing, a composition for orchestra and laptop by the 38 year old composer Mason Bates. The piece musically depicts synthetic computing, in which lines of code are replicated without human intervention. Thus, it presents Cisco's product—networking technology—as art.

Bates, a Juilliard-trained symphonist and techno DJ, has attained some of the highest markers of prestige that arts institutions can bestow: he has won a Guggenheim and a Rome Prize, for example, and in the 2014/15 concert season he was the second-most performed living composer in the U.S. (after John Adams). However, he is also patronized by tech corporations like Google and Cisco, and has written programmatic works extoling their virtues. His supporters in both realms uphold him as a "maverick" and an "innovator" whose use of digital technology is changing the face of classical music in America.

I examine some of Bates's work-Exotic Computing, Mothership, and his creative partnership with the YouTube Symphony Orchestra_as well as the journalistic, institutional, and corporate rhetoric promoting him. Bates and his supporters routinely deploy revolutionary language about freedom and individuality while actually serving the interests of capital, which is an important feature of neoliberal rationality. Ultimately, I argue that Bates has achieved his success primarily by aligning not only his music but, by extension, "classical music" itself, with the values of America's neoliberal elite. 